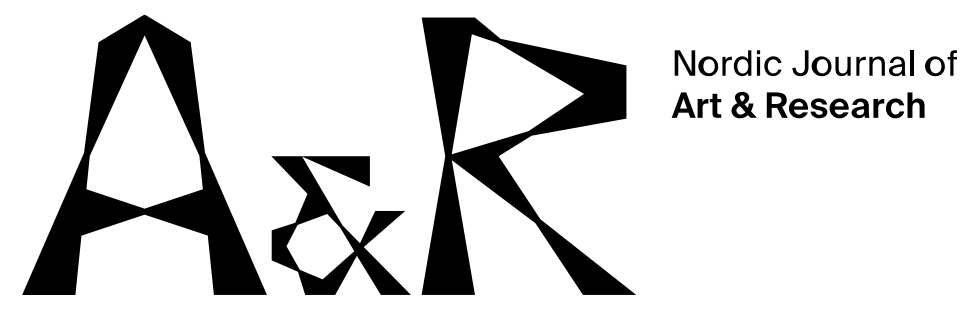

\title{
Contemporary art as democracy education
}

\author{
Inger Fure Grøtting ${ }^{1}$
}

\begin{abstract}
Democracy education, which is a fundamental part of the Norwegian school model, has in recent years become especially significant in national and international political climates, which have been characterised by an increased polarisation. As seen through the lens of Hannah Arendt's political theory conceived in the wake of World War II and affected by the anxiety of totalitarianism, excessive polarisation of political debates leads to the disappearance of a free public space where different voices can be expressed and heard. According to Arendt, a free and public space is an essential condition for democracy to exist. In order to maintain a democratic social model, the school system needs to facilitate these open spaces for dialogue, where students can acquire knowledge, develop the skills and values they need to become active democratic citizens and receive practical training in exercising them. This article aims to explore how an art institution can become a genuine open and public space, where students' encounters with contemporary art can contribute to democracy education. The argumentation is based on research from a case study at Kunstnernes Hus, where students from an upper-secondary school encountered artworks by Vanessa Baird.
\end{abstract}

Keywords: democracy education, democracy and citizenship, social science, art education, contemporary art 
Inger Fure Grøtting. Contemporary art as democracy education

\section{Introduction}

If everyone dares to say what is in their head, in their heart, then we can make a great change. (Upper secondary school student Fatima, referring to Vanessa Baird's artwork)

Today's students are the ones who will inherit the world we live in and pass it on to the next generation. They are the ones who will be challenged to maintain democracy in a climate of increasing political polarisation and sharper rhetoric in a future full of uncertainties. Democracy education and facilitating active citizenship among children and young adults is therefore a cornerstone of the Norwegian school model. This dimension will be further strengthened in the new curriculum that comes into force in Autumn 2020, in which 'democracy and citizenship' will be one of three overarching and interdisciplinary topics that will be applied to all subjects.

According to Hannah Arendt, one of the most important figures of 20th-century political thought, a free and public space where different people can act and speak is a precondition for democracy to exist and is a counterforce to totalitarian ideologies (Vetlesen in Arendt, 2012, p. 11). Furthermore, Mikhail Bakhtin, one of the central thinkers in dialogical theory, claims that meaning, understanding and knowledge are created in conversations between different people and thus are dependent on people expressing themselves together. He argues that this fundamental value of 'the other' will always influence our way of thinking and speaking; it is not I who creates truth, but we (Bakhtin, 1984, p. 284-287; Dysthe, 1995, p. 71). Thus, 'the other's' voice becomes part of the utterance, as we utter ourselves with respect to the people we interact with. In such a perspective, Bakhtin's dialogue is a prerequisite for a democratic society (Dysthe, 1995, p. 71).

One of the unique qualities attributed to art, especially contemporary art, is that the aesthetic expression associated with it can be perceived and interpreted differently depending on the spectator. The background, previous experiences and knowledge of the spectators are important factors that influence their subjective experiences. Furthermore, art has a rich repertoire of source material, with motifs from political, historical and social particularities that reflect its times, such as in the case of contemporary art being an expression of the times in which we live in. Art institutions might, in this sense, function as one of these open spaces for dialogue, or what Arendt would call a space between us, where students can practice reflection and critical thinking and acquire the attributes they need to become democratic citizens. 
Based on research from a MA thesis in Didactics in Social Science examining qualitative case studies of art mediation (Grøtting, 2018), this article explores how a dialogue-based approach to contemporary art can contribute to democracy education. The purpose is not to present new mediation methods, but to give the reader deeper insight and a better understanding of how the use of interaction processes involving art can promote learning and contribute to democracy education. This article will present one of the cases in the mentioned research study, in which upper secondary school students encountered artworks by Vanessa Baird in her solo exhibition at Kunstnernes Hus.

This article will discuss the case study in light of Bakhtin's and Arendt's ideas. Although these thinkers did not necessarily write about the educational system or art institutions, their ideas may be transferable to these two contexts. Bakhtin's arguments rely on the proposition that dialogue is not only the most fundamental principle of human existence but is also indispensable for achieving the values and properties that are necessary for democracy to exist. Arendt also writes about the importance of dialogue, although indirectly. Her perspective on dialogue and democracy suggests that in order to avoid depoliticisation and withdrawal of the public, two qualities that conflict with democracy, citizens must experience being heard and seen by others and avoid staying enclosed in their own subjective world of experience (Slagstad, 2020). Norwegian schools have a clear mandate to prepare children and young adults to become democratic citizens. At the same time, students can live out democracy 'here and now' in the school community by allowing different voices to be heard and challenged. With this context as a backdrop, this article aims to explore the following research question: How can students' encounters with contemporary art contribute to democracy education?

\section{Democracy education - the mandate to schools}

According to several scholars, the population must learn how to be democratic citizens in order to maintain a democratic social model (Enslin, Pendlebury \& Tjiattas, 2001, p. 115; Stray, 2012; Arthur \& Wright, 2001). As all citizens must go through the school system, it has become a central and fundamental arena for promoting the values of the desired political outlook (Gutmann, 1995, p. 579). The goal of democracy education is articulated in both the curriculum and in the Education Act. The school's role in building democracy will continue and will be potentially strengthened in the new Norwegian curriculum that is gradually coming into force from Autumn 2020. The Ludvigsen Committee emphasises qualities such as 'being able to participate in discussions, manage conflicts and interact across inequalities 
and points of view' (NOU 2015:8, p. 30). Furthermore, the new curriculum has a strong focus on interdisciplinary work. Among other things, it highlights the need for more in-depth learning across subjects, as it is 'crucial for them when they later serve as (...) independent community citizens in a more complex society' (NOU 2014:7, p. 10). This interdisciplinary aspect is addressed in the present article by exploring the possibilities of approaching aesthetics in relation to (and not necessarily through the lens of) democracy education.

James Arthur and Daniel Wright (2001) developed a model comprising three different approaches that summarises the content of democracy education and lays the ground for the argument that we need several different education strategies for democratic citizenship. The model divides democracy education into three different levels: education about, for and through democracy. Education about democracy involves acquiring knowledge of the democratic political system. Education for democracy involves developing skills and values as a means of encouraging active citizenship. Education through democracy involves learning by doing through experiences in and outside of the school (Arthur \& Wright, 2001, p. 8). Arthur and Wrights' model is based on the British school system, while Jannicke H. Stray (2012) has developed the model to adapt it to the Norwegian context. Stray utilised the same three levels, including and distinguishing between intellectual competence (education about democracy), value/attitude competence (education for democracy) and action competence (education through democracy). The three levels build on each other and describe the process from theoretical learning to democratic practice.

Both the school curriculum and Arthur and Wright's model are in line with both Arendt's and Bakhtin's ideas of democracy. When Arendt claims that a public space for speech and action is a prerequisite for democracy, she implicitly claims that this space must not only exist but be actively used. Thus, democracy education cannot only include education about and for democracy but must include education through democracy. The model is also in agreement with Will Kymlicka's (1999) ideas, wherein democracy and citizenship education are not only a matter of learning basic facts about the political system, institutions and procedures of political life. It also involves acquiring a range of skills and values, or what he specifically refers to as dispositions, virtues and loyalties that are strongly related to the practice of democratic citizenship. The research that this article is based on (Grøtting, 2018) attempts to explore how different competences in Arthur and Wright's model could be learned in the context of an art institution. 
Inger Fure Grøtting. Contemporary art as democracy education

\section{Democracy education - the mandate to art institutions}

The first public art museums in the Western context were established with an objective to provide an educational aspect to arts in order to elevate the population to become enlightened citizens of a democratic society. The humanist values of the Enlightenment based on the desire to inform citizens and develop a sense of national feeling served as a fundamental argument for the erection of museums (Bernhardt \& Esbjørn, 2012, p. 18). However, Bourdieu and Darbel (1966) clearly indicated that museums and galleries in Europe became spaces of exclusion: despite the fact that the usual audience of the museums was perhaps enlightened, the museums did not come off as particularly democratic as their audience group represented only a small portion of the population. In addition, the focus was on education norms that were already established; there was no questioning about cultural heritage. This situation gave rise to a new cultural-political paradigm through which art institutions came with a new set of questions (Sattrup, 2015, p. 3).

Accordingly, resent research in museology approaches art museums as learning arenas and suggests new perspectives on the stance that they can, and possibly ought to, adopt in this regard. Both art and museums, together with their mediation strategies, have been subjected to a shift from a modernist to a postmodernist view (Bernhardt \& Esbjørn, 2012, p. 26). For art, this resulted in a stronger focus on artwork as a part of social contexts and events (Illeris, 2005, p. 236). When it comes to the mediation and educational perspective, the museum is to a greater extent seen as a resource that facilitates the intellectual autonomy of visitors. Thus, a change in the perception of art institutions took place: from arenas of authority presenting a static narrative to their audience (which, in its part, is limited to assuming the role of a mere spectator), they became arenas for shared experience and exchange of views. This shift led to the audience becoming a co-producer of experiences and knowledge (Bernhardt \& Esbjørn, 2012, p. 25). The most prominent example of this shift is possibly Nicolas Bourriaud's conceptualisation of relational aesthetics (Bourriaud, 2007). Nevertheless, the idea of an active interaction between artworks and spectators can be applied to a much wider scope. For instance, Claire Bishop criticised Bourriaud for building on a harmonising model for participation and social artworks, whose spectators take a 'feel-good' position (Bishop, 2004, p. 79). In this article, participation and dialogue refer to practices exploring settings where students can learn skills and values as a means to become active democratic citizens. Although museums are regarded from a new perspective, they still maintain their position as a public space with the power to decide what is to be perceived as important for society. It is precisely for this reason that they can serve as active 
Inger Fure Grøtting. Contemporary art as democracy education

arenas for the public, not only taking artworks as isolated entities in the discussion, but rather, examining them through the lens of common experiences and a wider social context. Thus, museums and exhibition spaces can become arenas where we, as audience and citizens, ought to have the power to reflect on and debate about our values, for otherwise, without reflection, the museums and the society will be caught in a standstill (Bishop, 2013, p. 61).

\section{Case study at Kunstnernes Hus}

This article focuses on research that includes a qualitative examination of a case study in Kunstnernes Hus, where students from an upper secondary school encountered artworks by Vanessa Baird. Kunstnernes Hus is a fairly large art institution in Oslo with an audience of over a hundred thousand each year.

Established in 1930 to showcase both Norwegian and international art, it has since become one of the most important independent art institutions in Norway, specifically dedicated to contemporary art (Kunstnernes Hus, 2020). The following subchapter will give a brief presentation of the case.

In a large exhibition hall in Kunstnernes Hus, the walls were covered with colourful pastel crayon drawings on paper. The artist was Vanessa Baird, showcasing her work entitled You are something else (2017). Fifty-six drawings occupied all walls, measuring about 300 square metres. The drawings were expressive and detailed with complex motifs: some people were drowning in the sea while others were sunbathing on a beach. Nudity, sexuality, body openings, intestines, faeces and other abject matter were a recurrent motive. The drawings also included references to Edvard Munch's famous sunsets, Karl Ove Knausgård's controversial book My Struggle, SpongeBob and Little Red Riding Hood. One could also see a child lying lifeless on a beach while another one was typing on a smartphone under a parasol.

A group of approximately 20 students were visiting Kunstnernes Hus. All of them were upper secondary level 1 students, attending the Programme Area for Health Work. The group mainly consisted of females, with the participants aged 18 to 34older than most students at upper secondary schools. For most of the students, it was their first visit to an art exhibition. For everyone, it was the first time that they looked at and interpreted a piece of contemporary art. All of the students were firstgeneration immigrants and had backgrounds from war-torn areas. All of them had been living in Norway for a long time and they all spoke Norwegian very well or fluently. According to the mediator and written information that the teacher received in advance, the institution aimed to establish a dialogue with the students in order to 
Inger Fure Grøtting. Contemporary art as democracy education

interpret Baird's work, discuss with them and help them gain understanding of how art can be a channel for reflection on ethical issues in society.

\section{Methodology}

The research that this article is based on has sought to bring to light the peculiarities of the phenomenon being studied: students' encounter with artworks and how this meeting can contribute to democracy education. Consequently, the study employed method triangulation, which consists of using two or more methods of data collection in order to study the same aspect of human behaviour (Hellevik, 2002, p. 469). This involved observation, an individual interview with the mediator, as well as a group interview with students. These methods contribute to obtaining different perspectives that support the validity and reliability of the results and conclusions in the research study. Combining observation with qualitative interviews is relatively common in studies in this field, such as Aure, Illeris and Örtegren's (2009) studies of mediation at Nordic art museums, as well as Dysthe's (Dysthe, Bernhardt \& Esbjørn, 2012) studies on dialogue-based teaching at art museums.

A strategic selection was made when choosing the context for collecting the empirical data, which consists of selecting elements that are deemed revealing about the phenomenon being studied (Dalland, 2007, p. 91). An assumption was made that a case study at Kunstnernes Hus could provide materials for exploring the potential of democracy education in students' encounters with contemporary art. The researcher was not able to influence the selection criteria of student informants to any great extent. Several classes visited Kunstnernes Hus for this specific mediation programme. The choice of the class for observation was made only on the basis of the class schedules and the mediator's availability. In other words, the student informants were selected through convenience sampling (Maxwell, 2013).

Only one mediation sequence was analysed. This was done in order to be able to conduct an in-depth study, rather than remaining on the surface with several sequences. Five students were interviewed. The selection of students was done by their teacher, who was asked to choose a representative of their class. The students are originally from Somalia, Syria and Afghanistan. The mediator working at Kunstnernes Hus holds a degree in fine arts and has an extensive experience in art mediation.

All informants require ethical treatment since the interview is an asymmetrical situation (Kvale \& Brinkmann, 2009). Moreover, ethical considerations are particularly important in this study since the group of students consists of especially vulnerable 
informants. All of them have war and refugee backgrounds and thus have had experiences that can be linked to the topics in the artwork they encountered. It is necessary to clarify how this study deals with ethics of consent and confidentiality when relating to the students and the mediator. First and foremost, voluntary participation and informed consent are necessary for a study to be ethically justifiable (Kvale \& Brinkmann, 2009, p. 88). I gave the students an oral presentation of the research project before both observation and interviews. They also received a consent form to be signed if they were interested in participating in the study.

Furthermore, the confidentiality of informants is another important ethical aspect. All students were anonymised by using pseudonyms in line with the guidelines provided by Norwegian Centre for Research Data (NSD). The mediator was anonymised by not using a name and by only referring to him/her as "mediator". No other identifiable information is given on the students or the mediator. All interviews were recorded and then transcribed digitally. Anonymization of the informants took place already in the process of transcription. All audio recordings were deleted in May 2018. The study was reported and approved by NSD.

Maxwell (2013) points out two specific threats to validity in qualitative research: researcher bias and reactivity. Researcher bias concerns researcher's subjectivity, or lack of objectivity. One outcome of researcher bias may be that the researcher selects data that is in line with the research target or the researcher's preconceived understanding (Maxwell, 2013, p.124). This aspect is pertinent for this study, as I previously was employed at Kunstnernes Hus. I have carefully considered the use of case study at my own workplace with regard to researcher bias and have concluded that the advantages of using the case outweighed the disadvantages. The weighing factors for the decision were that my work tasks at the institution were different from mediation and that the mediators were hired externally for each exhibition period. I was employed on part time basis and was well acquainted with both the institution and the exhibition this case is based on. Maxwell emphasizes that it is impossible to be completely objective in quantitative research, and that it is therefore necessary to reflect on researcher bias (Maxwell, 2013, p. 124).

Furthermore, reactivity occurs when a researcher can influence informants through choices and actions, for example by asking leading questions. Maxwell emphasized the importance of being observant and conscious of it, since it is not possible to be completely unaffected in a social interaction (Maxwell, 2013, pp. 124-125). One way to prevent the validity threats of researcher bias and reactivity is to carry out a pilot survey in advance of the research interview itself (Maxwell, 2013, p. 66). I have 
Inger Fure Grøtting. Contemporary art as democracy education

conducted a pilot survey of the observation, the interview with the mediator and the interview with the students. Based on the pilot surveys I have adjusted the interview guide before the actual study.

The data were analysed in two rounds. First, the most relevant findings, which included descriptions, direct quotations and summaries, were structured on the basis of Aure, Illeris and Örtegren's model for institutional analysis (2009, p. 15). This analysis was further analysed based on Tjora's (2017) presentation of the step-bystep inductive method. Both processes were analytical, but in order to first present the data without including the theory, the two methods were approached separately. A distinct approach to these analyses was also taken in order to present a more comprehensive narrative that provides a better overview and a deeper insight to the reader, as well as out of a desire to present the data in such a way that the informants could immediately recognise their own quotes.

Three overall findings were distinguished in the review of the empirical data. These findings also emerged as markers of democracy education and can be seen in the light of Arendt's understanding of democracy. Therefore, the data were sorted within these three categories based on the characteristics of the empirical data and theory. The first category is the exhibition as what Arendt would call the space between us, where the students experienced an open space for speech and action. The second category deals with the fact that there are differences within the student group; the individual backgrounds and stories of the students were useful resources. The third and final category deals with art's own power of speech and action.

\section{The exhibition as a space between us}

First, the study showed that the students, at some level, established a pre-political community. The term suggests a community that can lead students to future political participation (Grøtting, 2018). This transition is possible as the mediation sequences gave the students the ability to acquire some of the attributes they need as democratic citizens.

Arendt claims that one expands one's thinking by making oneself informed with the thoughts and beliefs of others (Arendt, 1994 in Mahrdt, 2012, p. 201). Allowing individuals to speak, to be heard and to get the right to influence is arguably one of the basic ideas behind democracy. The student group at Kunstnernes Hus was highly differentiated: it consisted of students from a number of different nationalities and backgrounds. Different perspectives were confronted and challenged in the dialogical situation between the students, the mediator and the art. Selda, one of the students, 
Inger Fure Grøtting. Contemporary art as democracy education

said, 'Things are not always as you think or see them. Different people see life with a different pair of eyes'. Through the exchange of thoughts and experiences, the students evidently gained training in critical thinking, reflecting on their opinions, respecting others, as well as communication and collaboration. All of the abovementioned attributes are characteristics of education for democracy.

When the interviewer asked the students how they experienced the conversation between them and the mediator, they all expressed that it stimulated a broader reflection and understanding. One of the students, Fatima, stated:

She first tried to tell us what she thought about the artwork and what the artist had in mind. Then, she also asked us what we thought of the work. She tried to tell us as much as possible, so that we could understand [the artwork].

Despite the fact that the mediation sequence mainly consisted of the mediator speaking most of the time, it did not present itself as a case where only one correct interpretation of the work was acceptable. On the contrary, the mediator made several of the students assume that they could have their personal interpretations of the art by presenting her own thoughts about the art, the artist's idea, as well as letting the students' own voices be heard and challenged. Furthermore, another student, Maria, said, 'At first I found it difficult to look at the pictures. For me, I was somehow back in a war situation (...) My feelings and thoughts changed when I heard what other students were thinking and feeling'. Fatima and Marias' quotes are examples on how the students in the group expanded their perspectives by acquainting themselves with the different viewpoints of the artist, the mediator and their fellow students, and this expansion of perspective is along the lines of Arendt's thinking.

It may seem that the exhibition space also functioned as a pre-political community because the students, at some level, learned what Stray (2012) refers to as action competence. This happened by letting the students live out democratic actions 'here and now' in the exhibition space and, perhaps most of all, during the discussions that took place after the visit. This was evident in the fact that the students were encouraged to make up their opinions and articulate them, listen to and respect others and take a stand on the point of view of the mediator and their fellow students. By facilitating learning by making experiences, art mediation sequences can provide democracy education through democratic participation (Arthur \& Wright, 2001; Stray, 2012). When Arendt argues that a public space for speech and action is a 
prerequisite for democracy, she implicitly argues that this space must not only exist but be actively used. Thus, Arendt's thought is in line with Arthur and Wright's three levels of democracy education (Arthur and Wright, 2001, p. 8). In their model, democracy education cannot include only education about and for democracy but must also include education through democracy. The case study shows itself as an example of how an exhibition space may function as an active public space or a starting point for practicing active citizenship. Still, if the students had more time for practical training, by the mediator opening up for even more discussion and possibilities to live out these democratic values and attributes in the actual mediation sequence, the exhibition space might have functioned as a pre-political community to an even greater extent.

Many of the students acquired new perspectives and comprehension through dialogue. They gained these, not only in relation to the artwork itself, but also in the social contexts associated with it. A quote by Fatima illustrates this: 'I spoke to Sahar and she explained to me that they [some of the figures in Bairds drawings] were refugees, and then I began thinking differently. I changed my mind when I heard her opinions'. As Arendt claims:

I form an opinion by considering a given issue from different viewpoints, by making present to my mind the standpoint of those who are absent; that is, I represent them. (...) The more people's standpoints I have present in my mind while I am pondering a given issue, the better I can imagine how I would feel and think if I were in their place, the stronger will be my capacity for representative thinking and the more valid my final conclusions, my opinion (Arendt, 1968, p. 241).

Arendt's claim is also in line with Bakhtin's idea that it is not I who create truth, but we (Bakhtin, 1984, p. 110).

It appears that several students in the group also acquired a wider understanding of the Norwegian majority, an understanding that was previously lacking despite a long residence time in Norway. One of the students, Amina, said that she knew only a few ethnic Norwegians other than her teachers. Her impression of Norwegians was mainly formed by the comment fields in social media fuelled by fear and hate towards minorities. When Amina first entered the exhibition space at Kunstnernes Hus, the drawings reinforced these impressions even further. However, through the dialogue on Baird's work with the mediator, her fellow students and teachers after the sequence, her impression of the attitudes of Norwegians became more nuanced: 
'Now, the bad feeling I had is gone. (...) now, I have a feeling that people are different', she shared. By taking into account Amina's experience of Norwegian culture, the Norwegian majority can also gain new understandings about how it behaves, accepts or welcomes new cultures. Amina's experience is very important for both mediators and teachers, in terms of being aware of it in the mediation setting and in the classroom. As Bakhtin writes:

It is only in the eyes of another culture that foreign culture reveals itself fully and profoundly [...] A meaning only reveals its depths once it has encountered and come into contact with another, foreign meaning [...] We raise new questions for a foreign culture, ones that it did not raise itself; we seek answers to our own questions in it; and the foreign culture responds to us by revealing to us its new aspects and new semantic depths. (Bakhtin, 1986, p. 7).

Exchange of opinions and perspectives challenges the subjective truth - both at individual and group levels within a given culture or society. Meetings with visual art can thus challenge opinions and perspectives in different ways in new cultural contexts, in the same way as oral or written utterances Amina's quote is an example of what Bakhtin's writes here. Apparently, she expanded her thinking with the artwork as a starting point for dialogue, but she also may have contributed to expanding the worldview of others by discussing her experience as a spectator with others.

The mediation sequence at Kunstnernes Hus was mainly characterised by the mediator speaking most of the time. Although the students did not have such a high degree of what Arthur and Wright would call education through democracy, they apparently received a lot of training for democracy. First, they did this through the silent dialogue. A dialogue for Bakhtin is not only based on explicit oral expressions. He claims that communication is dialogical on the condition that a conversation has room for doubt, questions and contradictions, and on the condition that immediate answers are replaced by searching for different solutions or interpretations (Igland \& Dysthe, 2001). Despite the students' low degree of oral activity, the mediation sequence evidently did meet Bakhtin's requirement. Observation as a method did not enable gaining any knowledge about the silent dialogue, and it might in fact seem that the dialogue did not occur at all since the students received a limited amount of time to express themselves during the mediation sequence. However, the interviews with the students clearly indicated that silent dialogue did in fact occur and that they were highly influenced by the dialogue between them and the work, their dialogue with the mediator and their dialogue within the student group. The students also 
Inger Fure Grøtting. Contemporary art as democracy education

reflected on the exhibition later on, and discussed impressions and thoughts with the teachers, fellow students and others.

Furthermore, it appears that several of the students extended their understanding of the actual themes they associated with the artwork. This became apparent first and foremost through the discussions during the group interview. Baird's drawings served as a starting point for storytelling about their own lives, but also sparked longer discussions on current political cases. According to the students, these discussions mostly took place after the mediation sequence, between the students, as well as during the interview. The discussions touched on a number of topics including political climate in their homelands, in Norway and in the US, as well as migration, refugees, EU's border control, use of torture, sexual abuse, discrimination, free speech and the right to education. After experiencing that just one exhibition had the potential for sparking political discussions on a wide array of different topics, Fatima said:

If the politicians would see this exhibition (...) then they might understand the situation of many people in the population (...) Instead of our student group, it might have been better if it were the politicians who entered the exhibition and understood what is happening in society.

This instance of thought exchange within the group thus became a room for Bakhtin's interaction process, or what Arendt would refer to as the 'space between us'. This way, with the artwork as a starting point for discussions, the students acquired knowledge about phenomena and issues that citizens of democratic societies must deal with throughout their lives. Thus, they seemed to receive education about democracy.

\section{Polyphonic mediation as a resource}

Arendt writes that human plurality, a basic condition of both action and speech, manifests itself in two ways: as equality and inequality. Without equality, Arendt claims, people will not be able to understand each other nor will they make plans for a future world without themselves. Without inequality, on the other hand, there is no need for either language or action to communicate because every individual is absolutely identical to everyone else who is alive, has lived before or is going to live (Arendt, 2012, p. 176). The case study at Kunstnernes Hus distinguishes itself especially in line with Arendt's idea. The exchange of views and ideas among the students demonstrated to them that meetings between different individuals facilitates mutual understanding. This is in line with the Norwegian Education Act (1998, § 1-1), 
which states that 'Education and training must provide insight into cultural diversity and show respect for the individual's convictions. They are to promote democracy, equality and scientific thinking'. Furthermore, the overarching and interdisciplinary part of the new Norwegian curriculum states that a democratic society rests on the fact that the entire population has equal rights and opportunities to participate in decision-making. All participants in the school community must develop awareness of both minority and majority perspectives and create a space for collaboration, dialogue and debate (The Norwegian Directorate for Education and Training, 2020). The present study shows that contemporary art exhibitions may function as this type of space. Through dialogue with the mediator, teachers and each other, the students evidently extended their thoughts and opinions about the artwork and other topics that the artwork thematised.

All of the students in the case study had backgrounds from war-torn areas, and they were reminded about their own stories when they entered the exhibition space. Two of the students reacted strongly and wanted to leave the room immediately, but eventually chose to participate in the mediation sequence. All of the students were enthusiastic about the exhibition during the interviews after the mediation sequence. The two mentioned students showed great involvement in particular. This example illustrates the importance of spaces for collaboration, dialogue and debate, as highlighted by Arendt, Bakhtin, the Education Act and the curriculum.

Everyone has prior experiences that affect the way one experiences different artworks, regardless of whether the prior experiences are directly related to the theme of the artwork or not. This is the reason why an encounter with art can become a democratic act in itself (Sattrup, 2015, p. 29). The student group at Kunstnernes Hus was a vulnerable audience group with regards to the thematic content of the exhibition, a detail that particularly indicates the importance of discussion and exchange of opinions. Nevertheless, discussion and exchange of opinions are important for all groups and students. Students should always be introduced to a set of different points of view and reflections because individuals form their opinions based on their social and cultural backgrounds. Thus, they will be prevented from being left in the echo chambers of their opinions. As Arendt writes, in order to avoid totalitarianism and in order to build democracy, citizens must be heard by others from a position of equality and not be locked in their own subjective world of experiences (Vetlesen in Arendt, 2012, p. 11). This idea ought to also apply in the setting of a classroom and an exhibition space. A striking example for one student may be meaningless to another. Experiences that students bring from their homes, living 
Inger Fure Grøtting. Contemporary art as democracy education

areas or previous schooling determine the examples and explanations that make sense to them. Arendt writes that the notion that the strongest person has the most power is false (Arendt, 2012, p. 192). Her claim is confirmed in the case study. The students had to work together to create meaning during their encounter with the artworks.

\section{The artwork's own power of speech and action}

Arendt writes that a work of art conveys history regardless of the master's name: 'Action without a name, a "who" attached to it, is meaningless, whereas an artwork retains its relevance whether or not we know the master's name' (Arendt, 1958, p. 180-181). She indirectly claims that art possesses power for speech and action when it encounters the spectator, and that it is the spectator who attributes a meaning to an artwork. This power of visual expression described by Arendt might not appear to be particularly striking for most artists, mediators or teachers. Nevertheless, there is a distinct lack of awareness around it. As long as this power is a surprise for students, more focus should be dedicated on visual expressions. Students in the case study at Kunstnernes Hus commented on this aspect as well. 'Art tells stories through visual images. Many people write in newspapers, but she [the artist] tells her opinions here instead', Sahar asserted during the mediation sequence.

This topic continued in conversations within the student group in school after the mediation sequence. Throughout the group interview, the students kept coming back to the fact that their experiences of the visual expressions were much stronger than that of written text or oral speech. Amina narrates:

When I entered the exhibition space, "bam"! I reacted a lot. There were a lot of strange things to look at, a lot of secrets we must talk about and do something about that is not being dealt with today. I want those in power to see this exhibition. I hope it can make a change.

Another student, Maria, mentioned, 'I reacted more intensely to this exhibition than when reading news articles or posts in social media. Art is stronger'. Fatima continued:

When you look at social media, you just scroll up or down or open a new tab. You refuse to accept the truth. But when you enter that exhibition space... If you scrolled to new pages there, turned in different directions, you couldn't get away. They were all over the place-those unpleasant things you couldn't bear to look at. One thing is stranger than the other. 
We, as teachers and mediators, need to make students more cognizant of this potentiality embedded in art, as well as to be more aware of how the visuals can speak to the spectators, the students, in very different ways.

According to Bakhtin's understanding of text as a term, the artwork, the aesthetic text, is a subject rather than an object (Børtnes, 2006, p. 103). Such understanding suggests that the observer, the student, can even enter in a dialogue with the artwork itself. The case study at Kunstnernes Hus illustrates several specific examples of such dialogue. 'Upon entering the exhibition space, I got flashbacks from everything I have experienced myself', Sahar related. This impression may be applied to all the informants in the case study at Kunstnernes Hus, where the students stated that they experienced Baird's drawings as stories from their own lives. They also engaged with the drawings as if they told stories about other lives, different lives, stories they thought were told through art. Yet, as Arendt writes, in the absence of the artist, a work of art can stand by itself and speak for itself, regardless of the master's name once it has been created. In this regard, Amina's quote is particularly striking:

I thought the exhibition was trying to get people to think about things. Like war, womanhood, poor and rich, and how things are in real life. How a human life really is. (...) The woman who drew these pictures might have thought that people have many secrets. That there are a lot of stories that should be told but no one tells.

In art, we find many examples of descriptions of complex and abstract topics that some people may find difficult to talk about. Baird's artwork is a clear example of such art, infused with themes such as abuse, sexuality, violence and refugees. The case study at Kunstnernes Hus indicates that visual and oral dialogue lean on and reinforce each other if they occur in interaction. In many cases, it may be easier to talk about topics when they are related to a work of art because the topics are thus perceived to be less personal and close (Opstad, 2010, p. 132). At the same time, the topics may also be strictly personal because the visual affects the spectator differently from written text. In this case, the dialogue may stop, but it can also cause the dialogue to become more open. This proved to be a relevant aspect for the student group at Kunstnernes Hus. The conversation about the work led to the telling of very honest and open stories about the students' own lives. This did not take place during the mediation sequence itself, but afterwards. One of the Afghan students, Sahar, shared: 'I think it was particularly painful to see all the people who were lying in the sea. (...) The drawings told a story that was mine'. During the interviews, 
Inger Fure Grøtting. Contemporary art as democracy education

several of the students mentioned very specific, self-experienced events that they associated with the artwork. Sahar continued:

When I entered the exhibition space, I got flashbacks to everything I have experienced myself. (...) We had to flee (...) over the Mediterranean. If we survived, it was good. If we drowned in the sea, then it was still better than to be where we were. To die one day is better than dying every day because that was how it felt.

Another student, Amina from Somalia, said: 'I have been through many wars. I have witnessed girls being raped. I started to think of all of this as soon as I saw the drawings. The students' stories continued in the same nature, and they showed that all of the informants experienced Baird's work as personal and close. It depends on the student group whether the artworks affect the spectators in such a way that it fosters a ground for an open dialogue, yet it mostly depends on the method employed by the mediator. Students can develop the ability to reflect on their own values and actions, as well as solidarity with others through an open and exploratory setting - aspects that are fundamental to democracy education (Arthur \& Wright, 2001; Stray, 2012). In addition, art may stimulate students to reflect on issues that citizens in democratic societies are reluctant to deal with if art is regarded in connection with major challenges in society.

Baird's art addresses complex societal issues. Regardless of the students' personal experiences, Baird's works may be suitable for discussion as several viewpoints are likely to be represented in the classroom. The mediation sequence at Kunstnernes Hus was largely characterised by the mediator's expressions rather than those of the students. Perhaps the value of different voices, conflict and debate being at the core of democracy, would appear more apparent if the mediator allowed more space for the students' expressions during the mediation sequence. In such a case, the students would also receive training through democracy to a greater extent.

The mediator at Kunstnernes Hus stated: 'Contemporary art is always so ugly and weird. That's because we haven't seen it before. (...) It does not primarily follow the frameworks, conventions and rules that already exist, or the visual expression already established'. Based on the foregoing quote, as well as other interviews in the present research, it can be argued that a piece of contemporary art can lead to discussions that challenge the problematic aspects of society, and this is valid even in cases where an artwork is not evident in its thematic content. Thus, a dialogue- 
Inger Fure Grøtting. Contemporary art as democracy education

based approach to art can bring new perspectives and stimulate reflection and critical thinking about complex problems in society.

\section{Conclusion}

An understanding of democracy based on Bakhtin's and Arendt's perspectives, as well as on Arthur and Wright's model of democracy education, is relevant and appropriate for discussing democracy education as it corresponds with the Norwegian government's standpoint on education policies. The fact that the new curriculum has integrated democracy and citizenship as one of its three overarching and interdisciplinary topics might draw more focus to this dimension and strengthen its importance. Nevertheless, democracy and citizenship education has been one of the fundamental parts of both the Education Act and the curriculum for decades, implementing a set of principles that shape the entire school system.

The case study presented in this article demonstrates that students may develop new insights, values and abilities for democracy when given an opportunity to express their thoughts and experiences in hindsight. The fact that a large part of the dialogic aspect appeared among students, teachers, and the interviewer after the mediation sequence (and not only between the students and the mediator) may indicate that a closer collaboration between the school system and the art institutions can be fruitful. There are a few art institutions that prepare mediation programs based on competence goals prescribed by the curriculum. They do it, in order to, among other things, make it more practical for the school system to continue working with the art experience in ordinary teaching. Unfortunately, there are few arenas where mediators can exchange experiences and reflections with teachers and students after the mediation event. This lack of feedback is challenging in terms of evaluating the experiences received out of mediation programs and thus creates barriers to adjust for future exhibition visits. Hopefully, case studies like the one presented in this article, may inspire teachers and mediators to collaborate more closely and to create arenas for exchanging ideas and experiences. The fact that the new curriculum has a strong focus on interdisciplinary work, for example by having 'democracy and citizenship' as one of the overarching and interdisciplinary topics that will be applied to all subjects, can potentially promote more of such collaborations.

How students' encounters with contemporary art can contribute to democracy education is a complex question. Although this article does not provide a complete answer, it aims to give the reader a deeper insight and understanding of how these principles can be attained in an exhibition space. Fatima, one of the students, said: 
We blame the politicians, but we, the people, are the ones who are guilty. It is our task to change society. I believe that if everyone dares to say what is in their head, in their heart, then we can make a great change.

Fatima's assertion confirms that contemporary art can lead to the formation and exchange of opinions, raising curiosity on social issues and creating social engagement among students. Thus, Fatima's quote summarises this article and the findings in the present study, and also highlights the importance of being aware of the visual approaches to democracy education.

\section{About the author}

Inger Fure Grøtting is the Head of Education for the Norwegian Annual Art Exhibition, Høstutstillingen, hosted by the Association of Norwegian Visual Artists. This article is based on parts of her MA-thesis in Didactics of Social Sciences from the University of Oslo. Her research and practice focus on interdisciplinary mediation in art institutions, collaborations between the art field and the school system, as well as dialogue based education.

\section{References}

Arendt, H. (2012). Vita activa - Det virksomme liv. Oslo: Pax Forlag.

Arendt, H. (1968). Between Past and Future: Eight Exercises in Political Thought. Harmondsworth: Penguin.

Arendt, H. (1958). Human Condition. Chicago: The University of Chicago Press.

Arthur, J. \& Wright, D. (2001). Teaching Citizenship in the Secondary School. London: David Fulton Publishers.

Aure, V., Illeris, H. \& Ortegren, H. (2009). Konsten som laranderesurs. Skärhamn: Nordiska Akvarellmuseet, forfättare och fotografer.

Bakhtin, M. (1984). Problems of Dostoevsky's poetics. Minneapolis: University of Minnesota Press. https://doi.org/10.5749/j.ctt22727z1

Bakhtin, M. (1986). Speech Genres and Other Late Essays. Austin: University of Texas Press.

Bernhardt, N. \& Esbjørn, L. (2012). Undervisning på kunstmuseer - en kort presentasjon av feltet. In Dysthe O., Bernhardt N. \& Esbjørn L. (Eds.), Dialogbasert undervisning. Kunstmuseet som læringsrom (p. 15-43). Bergen: Fagbokforlaget. 
Inger Fure Grøtting. Contemporary art as democracy education

Bishop, C. (2004). Antagonism and Relational Aesthetics. October, 110, 51-79. https://doi.org/10.1162/0162287042379810

Bishop, C. (2013). Radical Museology. London: Koenig Books.

Bourdieu, P., \& Darbel, A. (1966). L'amour de l'art: les musees d'art europeens et leur public. Paris: Ed. de Minuit.

Bourriaud, N. (2007). Relasjonell estestikk. Oslo: Pax Forlag A/S.

Børtnes, J. (2006). Bakhtin, dialogen og den andre. In Dysthe, O. (Eds.), Dialog, samspel og læring (pp. 91-150). Oslo: Abstrakt forlag.

Cohen L., Manion, L. \& Morrison, K. (2011). Research Methods in Education. New York: Routledge.

Dalland, O. (2007). Metode og oppgaveskriving for studenter. Oslo: Gyldendal Akademisk.

Dysthe, O. (1995). Det flerstemmige klasserommet: skriving og samtale for a lære. Oslo: Ad Notam Gyldendal.

Dysthe, O., Bernhardt, N.\& Esbjørn, L. (2012). Dialogbasert undervisning. Kunstmuseet som læringsrom. Bergen: Fagbokforlaget.

Education Act. (1998). Act relating to Primary and Secondary Education and Training (LOV-1998-07-17-61). Lovdata. https://lovdata.no/dokument/NLE/lov/1998-07$\underline{17-61}$

Enslin, P., Pendleburry, S. \& Tjiattas, M. (2001). Deliberative Democracy, Diversity and the Challenges of Citizenship Education. Journal of Philosophy of Education, 35(1), 115-130. https://doi.org/10.1111/1467-9752.00213

Grøtting, I. F. (2018). Samtidskunst som samfunnsfag. (Master thesis). University of Oslo, Oslo.

Gutmann, A. (1995). Civic Education and Social Diversity. Ethics, 105, 557- 579. https://doi.org/10.1086/293727

Hellevik, O. (2002). Forskningsmetode i sosiologi og statsvitenskap. Oslo: Universitetsforlaget.

Igland, M-A. \& Dysthe, O. (2001). Mikhail Bakhtin og sosiokulturell teori. In Dysthe, O. (Eds.), Dialog, samspel og læring (pp. 107-127). Oslo: Abstrakt Forlag

Illeris, H. (2005). Young People and Contemporary Art. International Journal of Art \& Design Education, 24, 231-242. https://doi.org/10.1111/j.14768070.2005.00446.x

Kunstnernes Hus. (2020). About us. Obtained from https://kunstnerneshus.no/en/about

Kvale, S. \& Brinkmann S. (2009). Det kvalitative forskningsintervju (2. utg.). Oslo: Gyldendal Akademisk. 
Inger Fure Grøtting. Contemporary art as democracy education

Kymlicka, W. (1999). Education for Citizenship. In Halstead, J. M. and McLaughlin, T. H. (Eds.), Education Morality. London: Routledge.

Mahrdt, H. (2012). Hannah Arendt - politisk dannelse og reflekterende dømmekraft. Norsk filosofisk tidsskrift, 47, 193-205. https://doi.org/10.18261/ISSN15042901-2012-03-05

Maxwell. (2013). Qualitative Research Design. Los Angeles: SAGE Publications.

NOU 2015:8. (2015). The School of the Future - Renewal of subjects and competences. Obtained from https://www.regjeringen.no/en/dokumenter/nou2015-8/id2417001/

NOU 2014:7. (2014). Elevenes læring i fremtidens skole - Et kunnskapsgrunnlag. Obtained from https://www.regjeringen.no/no/dokumenter/NOU-20147/id766593/sec2

Opstad, K. D. (2010). Estetisk dannelse - estetiske fags bidrag i skolenes dannelsesperspektiv. In M. Brekke (Eds.), Dannelse i skole og lærerutdanning (pp. 124-144). Oslo: Universitetsforlaget.

Sattrup, L. (2015). Jamen, hvad skal vi kigge efter? (Doctoral dissertation, Roskilde University). Obtained from https://skoletjenesten.dk/jamen-hvad-skal-vi-kigge$\underline{\text { efter }}$

Slagstad, R. (2020). Hannah Arendt - En tenker uten rekkverk. In Arendt, H., Politikk i dystre tider (pp. 9-69). Oslo: Pax Forlag.

Stray, J. H. (2012). Demokratipedagogikk. In Berge, K. L. \& Stray, J. H. (Eds.), Demokratisk medborgerskap i skolen (pp. 17-33). Bergen: Fagbokforlaget Vigmostad \& Bjørke AS.

The Norwegian Directorate for Education and Training. (2020). Core curriculum values and principles for primary and secondary education. Obtained from https://www.udir.no/lk20/overordnet-del/?lang=eng

Tjora, A. H. (2017). Kvalitative forskningsmetoder i praksis. Oslo: Gyldendal Akademisk. 